\title{
Historein
}

Vol 7 (2007)

History and Utopia

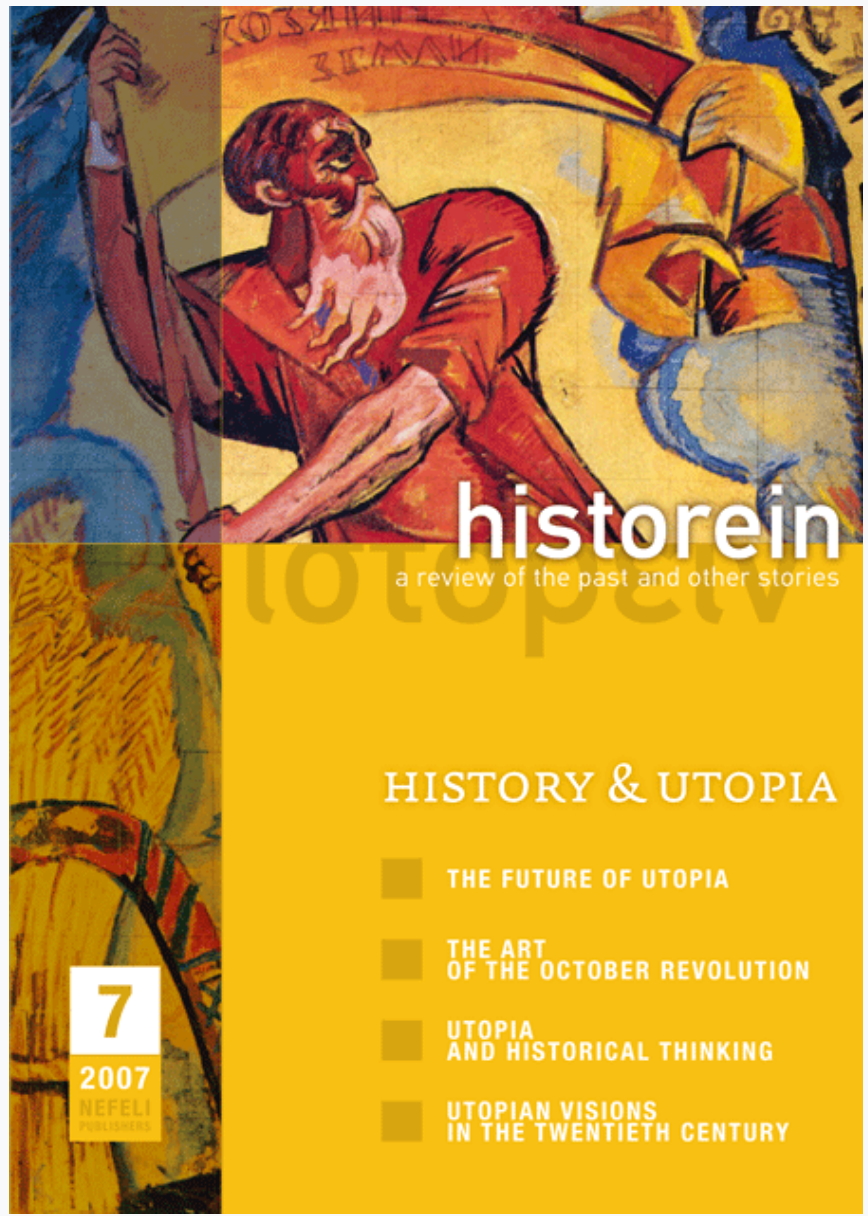

\section{Utopia and Reality in the Art of the October Revolution}

\section{Syrago Tsiara}

doi: $10.12681 /$ historein.52

Copyright ( ) 2012, Syrago Tsiara

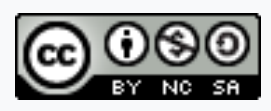

This work is licensed under a Creative Commons Attribution-NonCommercialShareAlike 4.0.

\section{To cite this article:}

Tsiara, S. (2008). Utopia and Reality in the Art of the October Revolution. Historein, 7, 86-102. https://doi.org/10.12681/historein.52 

prehend the written word, thus offering an adequate means of attracting broader strata of the population with revolutionary messages.

In order for the peasant and working classes to embrace the visions of a new society, a powerful offensive would have to be launched on their affect and subconscious; they needed new heroic models that could be comprehended and interpreted at once, models that were able to forge their emerging subjectivity. The industrial worker, the peasant, the revolutionary soldier, the man toiling for a living from day to day and the party member became the mirror for the identification of the subject and for his self-recognition in the new social conditions of a revolutionary reality.

Art played a decisive role in transforming Russian society and shaping the new Soviet citizen. Artists possessed the image-making means to set the stage for the new era and its heroic portraits. Artistic forms deeply rooted in Russian culture, such as troupes that made use of carnival elements and widespread popular engravings depicting the political issues of the time, were used to convey messages that could be easily understood. Religious icons - objects of worship but also an art form whose worth was recognised - offered a solid form of representation, whose codes were appro-
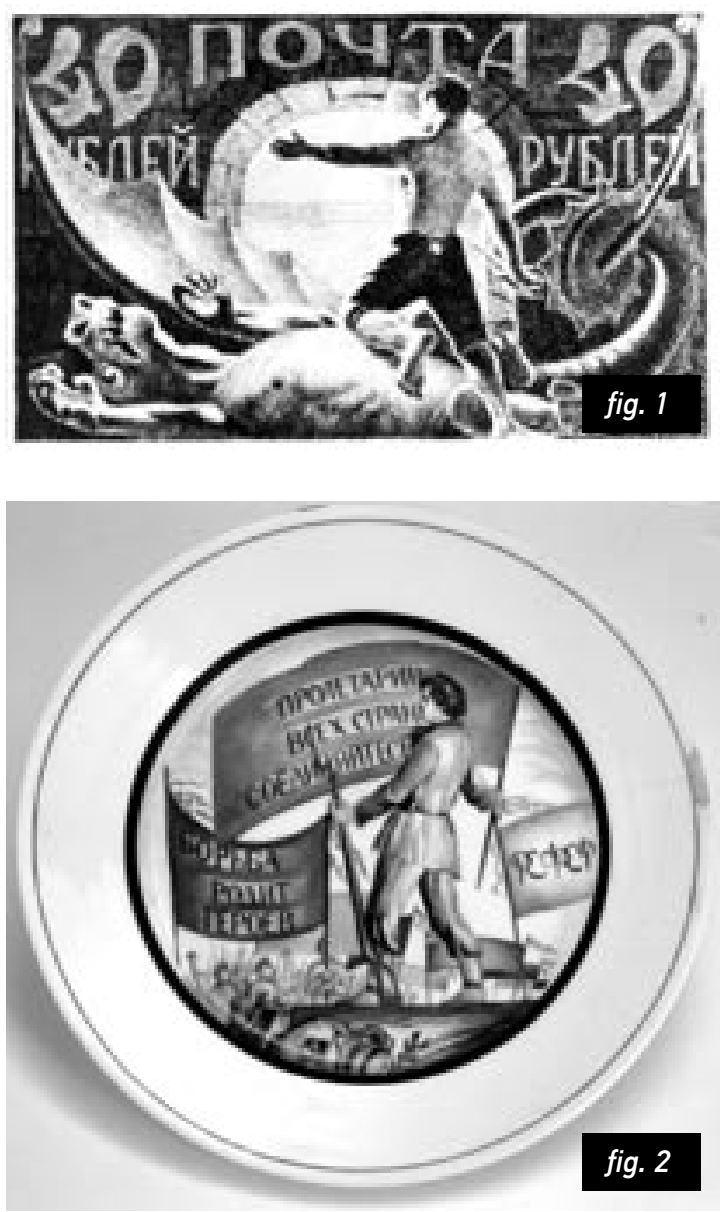

priated by revolutionary art with a different content. The Soviet Republic's propaganda posters and postage stamps (Figure 1) promoted the revolutionary soldier who, in adverse conditions, like a new Saint George succeeded in slaying the dragon of counter-revolution and imperialism. The porcelain of the former Imperial and subsequent State Porcelain Factory illustrated the everyday heroes who toiled to make a living, warriors of the Red Army and young proletarians bearing the banner of revolution. Artists like Nathan Altman and Mikhail Adamovich (Figure 2) used a more conservative, descriptive language, whereas Nikolai Suetin chose the supremacist forms as a better means for the dissemination of revolutionary messages. Excerpts from Lenin's speeches, the Communist Manifesto, and even Confucius and the Scriptures were employed as revolutionary slogans inscribed on the white ceramic surfaces. ${ }^{2}$

The People's Commissariat of Enlightenment invited artists to leave their studios and to participate actively in the decoration 
of streets, squares and public buildings for the celebration of two anniversaries that served as landmarks in the construction of the Soviet identity: the anniversaries of the October Revolution and May Day. Moreover, the propaganda trains (Figure 3) and lorries that travelled across the Russian countryside were painted with pictures and slogans of the Revolution, distributed revolutionary material, books and posters, and used loudspeakers to transmit Lenin's speeches. The Russian

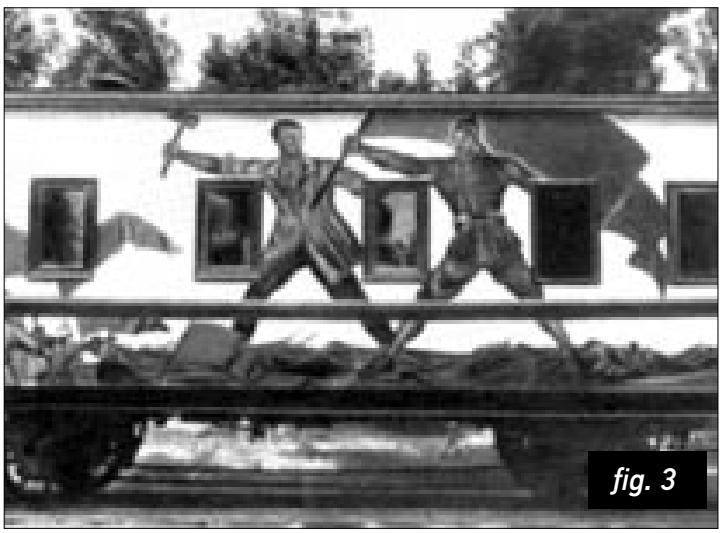
Telegraph Agency (ROSTA) windows (Figure 4) were important channels of communication as they replaced newspapers, creating a new type of news bulletin that frequently communicated the latest news with satirical illustrations, simplified forms and bold colours.

In the course of examining the relationship between the illustrative forms and structures of the religious icon and the artistic tools of the Revolution, one has to consider one major factor - transcendence. Transcendence is part and parcel of revolutionary art, and its concept is dual: it refers to the utilisation of the icon culture, but also alludes to the boundaries that were transcended in the art of the revolutionary period in order for it to assimilate the features of a new, superior reality which had yet to take place on a social level, but had nevertheless already been depicted.

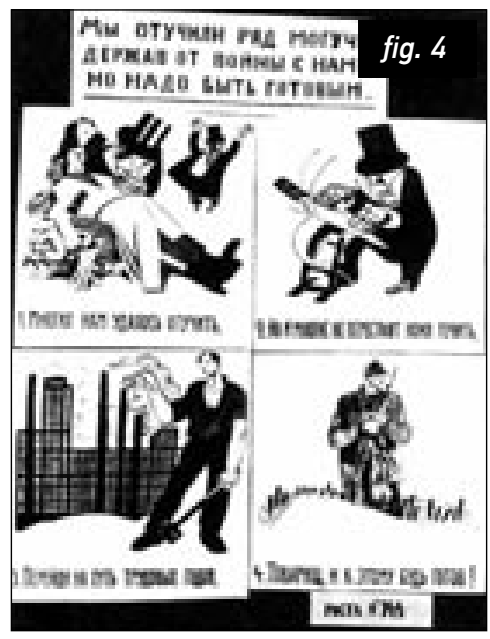

In order understand the Marxist perception of reality, we must look back to the tradition that emerged in the mid-nineteenth century. In his first philosophical texts, and in The German Ideology and Theses on Feuerbach in particular, Marx - as early as 1845 - put forward the materialist perception of reality as it evolved, which was summed up as the totality of the social relations that develop in specific historical conditions. Pointing out the gaps in previous materialist theories, he noted that Feuerbach had conceived reality in the form of the object (Objekt), "but not as human sense activity, not as practical activity, not subjectively". ${ }^{3}$ In Marx's view, the examination of reality divorced from the analysis of everyday practice was nothing but "scholastic". But because his purpose for examining reality was political, since he was interested in examining the mechanisms of change from one socioeconomic system to another, he focused his attention on the formation of a revolutionary consciousness in relation to the practice of severance: "The coincidence of the changing of circumstances and of human activity or self-changing can only be grasped and rationally understood as revolutionary practice."4

In The German Ideology he extended his reasoning to include a new term in the discussion, 
namely language. By expressing the opinion that language - as a system of communication - is a form of practical consciousness that ought to be viewed as a social product, he effectively laid the foundations for approaching ideology as a material, social process. ${ }^{5}$

For Marx, a revolutionary consciousness was a definitive precondition for socialism to succeed. Apparently even after the Soviet state was founded, the construction of a socialist consciousness via the materialist perception of reality remained a strong social need for which all intellectual forces had to be enlisted.

When Communist party secretary and close associate of Stalin Andrei Zhdanov put forward the "method of socialist realism" at the First Congress of Soviet Writers in 1934, as a consistent - albeit selective - Marxist, he invited writers to portray reality in the following way: "In the first place, it means knowing life so as to be able to depict it truthfully in works of art, not to depict it in a dead, scholastic way, not simply as 'objective reality', but to depict reality in its revolutionary development."6

For Zhdanov there exists no "pure historical reality". Reality is an ideological construction. It is perceived in political terms relating to the balance of power. Therefore art needs to compose the properties of the desired subject - that which emerges through revolutionary operations - and to foretell it with images, in this way fulfilling its guiding, instructive role. This role entails the promotion - through art - of models with which the emerging citizens will identify. With this in mind, one must dismiss the charge of "committed art", since art cannot be anything but committed, in Soviet thought.

Socialist art is characterised by a peculiar, "earthly" transcendence, since it strives to renegotiate utopia. The artist ought to rely on the material foundations of society and, deriving his inspiration from a new type of romanticism - one which is not bourgeois but revolutionary - to record the absolute severance from the past and to illustrate the heroes of the new era with historical precision, not as the protagonists of a utopian vision, but rather as conscious workers and creators of a constantly evolving present: "Soviet literature should be able to portray our heroes; it should be able to glimpse our tomorrow. This will be no utopian dream, for our tomorrow is already being prepared for today by dint of conscious planned work."

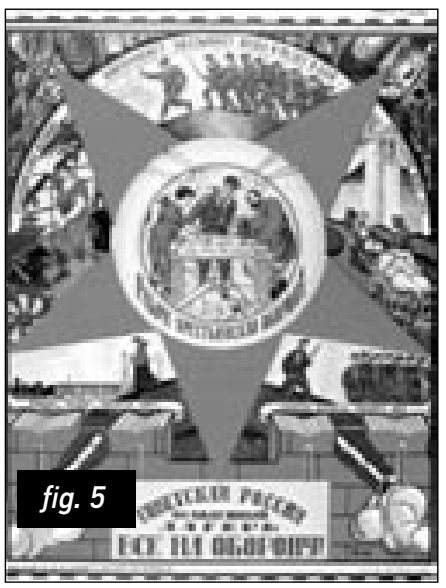

In 1919, Dmitry Moor invited citizens to defend their country from the White Army of counter-revolutionaries. This invitation was extended by means of a poster (Figure 5) of which 20,000 copies were printed by the Revolutionary Military Council of the Republic (Revvoensovet) and which combined in a unique manner the organised class of a system with a sense of gravity and a message of vigilance.

The system is made evident through the austere geometrical composition. The five-pointed red star is positioned in the cen- 
tre of the poster, dominating it with its size and lending structure to the entire picture. Depicted inside the inner circle are three upright, full-length figures: a peasant, a worker and a soldier studying a map spread out before them on a table, marking the progress of military operations. The soldier in the middle is speaking on the phone; behind him hangs another map while other rolled-up maps are bundled together under the table. The way in which the three men are positioned alludes to the arrangement of the figures representing the Holy Trinity in icons, with the middle figure dominating and the other two leaning towards the middle. This Trinitarian ensemble is surrounded by a ring of golden light, which - in praise of the new era - does not come from a celestial source but is instead emitted by protruding electric lamps which outline the perimeter of the ring of light. Along the bottom part of this bright band, in red writing, is the slogan: Workers - peasants in defence, ${ }^{8}$ while five scenes portraying the support mechanism of the Revolution are arranged around the star in the gaps formed between its five points. At the top, a communist points out the enemy and leads the army against it. The enemy is personified in the faces of a priest, a capitalist and a White Army soldier. Depicted clockwise around the central scene are: a farmer ploughing his field in order to feed the soldiers, young men training for war, a woman taking the place of a male worker in his mechanical tasks who is away at the front, and a blacksmith forging weapons. The main slogan Soviet Russia is a Camp under Siege. Defend it! is written at the bottom on a bastion wall with the revolutionaries' cannons to its left and right. The corresponding positions at the top of the poster are held by two sombre scenes representing heinous, pre-revolutionary reality: Hunger and Slavery. Hunger is symbolised by Death on his chariot, threateningly reaching for the crops with his skeletal hands, while a portly capitalist holds chains, symbols of class oppression.

Moor's poster is narrative, the scenes have been arranged in a strict geometrical manner around a central theme, there is use of allegory, and situations taking place at a different external time coexist concurrently. All these are structural elements of religious icon painting and the lubok, which revolutionary art appropriated so that it could be comprehended by a wider range of social strata. Of course, new codes were also developed; the Revolution's vocabulary gave birth to new expressive shapes and emblems, such as the red star for which a convincing relationship with tradition has yet to be established..$^{9}$ The red star and hammer and sickle made their appearance in early 1918 as the insignia of the Red Army, subsequently becoming an emblem of the Soviet flag and a vital element by means of which the Soviets defined their identity.

However, if we expand on our observations on the morphological analogies between propaganda art and religious or popular art, and bypass the loaning of icon motifs and the layout of the icon, we inevitably come to the definitive function of light. Light, as a metaphor and manifestation of spiritual energy, surrounds the figures of saints in the form of a halo. In Byzantine art, golden or white light is used allegorically to declare the supremacy of truth and virtue over the treacherous forces of spiritual darkness and sin. When studying the work of Russian artists in the early twentieth century, one should keep in mind the fact that "for any painter emerging from the Russian Empire, the icon-painting that came to medieval Russia from Greek Byzantium formed the plastic substratum, the bulk of the artists' visual and conceptual memory". ${ }^{10}$

Light, whether cloaking the portraits of the new heroes in glory, as in the portrait of the futurist poet Vasily Kamensky (Figure 6) painted in 1917 by David Burliuk, ${ }^{11}$ or whether structuring - in contrast 
with the dark surfaces - the non-objective paintings of Ivan Kliun and Liubov Popova, is at all times the transmutation of an internal energy. In the context of revolutionary art, light is used metaphorically as a symbol of the new era. As George Mosse has pointed out: "Socialists themselves cast their hopes for the future in the metaphor of rising from darkness to sunlight."12

Burliuk's portrait of Kamensky, a frontal portrait of his friend painted from life, uses warm, earthy colours. His face is surrounded by a bright white band along which runs the following inscription: "King of Poets, Song Champion, Futurist Vasily Vasilievich Kamensky. 1917. Russian Republic." This inscription announces the identity of the person portrayed and also the distinguished social role which he is called on to play at this historical juncture of the Bolshevik Revolution. The revolution did not only seek its leaders in the political and military arena, but also among the intelligentsia; poets and artists were called on to play a leading role not only

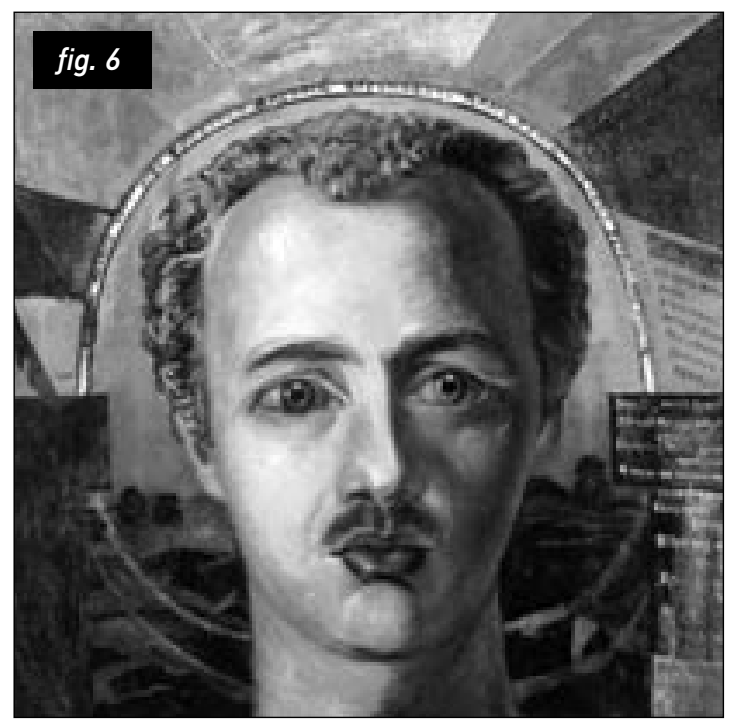
as an artistic but also as a social vanguard. Their ability to replace outdated expressive schemes with a new language, that of the futurist, opened new roads in which painters and poets intermingled in mutually interchangeable and complementary roles. In these early, optimistic years, the forward-looking, expressive language of futurism had not yet become something with which the wider range of social strata could identify.

Amassed on the right side of the painting are selected verses from Kamensky's poems and at the top of the picture, bands of warm colours emanate like rays from the bright white band. The poet's gaze is calm and penetrating, his forehead and cheeks have been formed using warm, earthy and golden tones that brightly illuminate the left side of his face, while on the right the darker tones are dominant. The firm flesh, the bold outline of his lips and the rounded shape of his face give life to a new type of saint: a young, healthy person whose spirituality does not marginalise him but instead makes him the focal point of the process of social reconstruction. The power to envision, which is made possible by the poet's strong personality, is indicated by the bold use of golden light on the canvas, a light that seems to originate from his very forehead, diffusing throughout.

If we view the issue from a technological and historical perspective, it is certain that some avantgarde artists such as Ivan Kliun and Liubov Popova succeeded in rendering light as an internal source by painting multiple, successive layers of colour on the canvas, a method known to them through the study of Russian icons which - due to new conservation techniques - were discovered in the early twentieth century in all their brilliance and chromatic grandeur. ${ }^{13}$ The connection that David Burliuk and the futurist circle had with Byzantine icon painting tradition is well known. Burliuk himself collected Russian icons and popular handicraft. ${ }^{14}$ 
This portrait, with its outspoken descriptiveness, its attachment to the symbolist codes of Russian modernism, the explanatory nature of the text in the painting and the rendering of an inner religiousness that sanctifies the person depicted, is placed historically at the watershed marking the transition from the old world to the new.

The distance between Burliuk's 1917 painting and the Apotheosis of the Worker ROSTA window (Figure 7), designed by Vladimir Lebedev in 1920-21, ${ }^{15}$ appears enormous. Using single surfaces of clear, bright colours, with schematic, simplified forms, adding text to the painting by way of elucidation, adopting a flat composition and rejecting descriptive features and details, the ROSTA windows abolished, in effect, the difference between information and propaganda, performing the supreme duty of offering an up-to-date report on developments on the various fronts of the Civil War, and the new decrees, slogans and principles of the Bolshevik

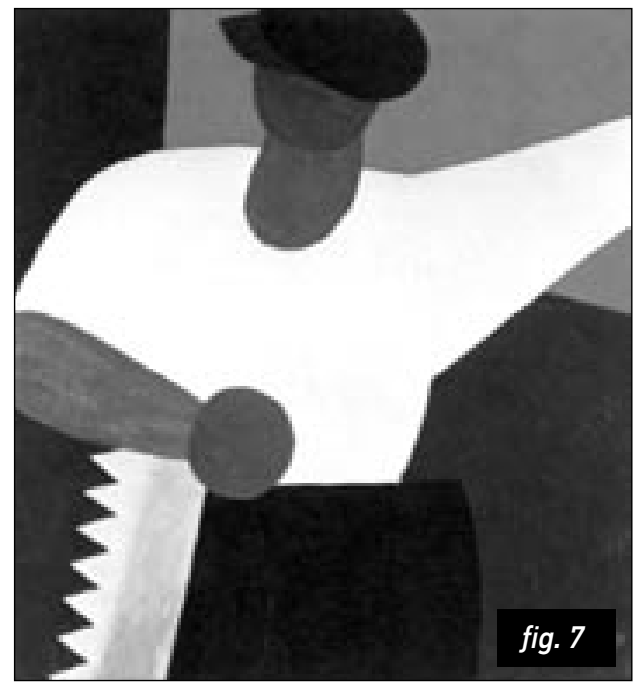
party. At the same time they were attempting a radical renewal of the visual vocabulary of graphic design. At first these posters were hung in the windows of abandoned shops, railway stations and recruitment offices in Moscow, but they were later to be seen all over Russia, the Ukraine and Belarus, "revolutionising" aesthetic perceptions as Vladimir Mayakovsky, creator of almost half of these posters, argued. ${ }^{16}$ Vladimir Lebedev worked in the studio directed by Vladimir Kozlinsky in Petrograd, producing ROSTA windows. Large numbers (about 2,000 copies) of the basic design were printed, and then painted in by apprentice artists, as had been the case with the lubki a century earlier. ${ }^{17}$

The monumental elevation through art of the anonymous hero was an important innovation which occurred during the early years of the revolution, visible in ROSTA art and posters. Gradually forsaking the conventional figures of poets, philosophers and political leaders, artists and sculptors now introduced into their thematic repertory peasant labourers, miners, bakers and peasant women. This change in subject was of course related to the nineteenth-century realistic tradition, invented by the French school of painters.

It is true, of course, that from 1848 onwards the labour of the peasant had been elevated to a theme deemed worthy of depiction in its own right in French art. A number of artists, chief among them Courbet and Millais, had turned their interest to the depiction of scenes of everyday toil. Yet there was an inherently idealised feeling in the way they approached their humble subjects, not unrelated to the reaction caused by the industrial revolution and the urbanisation of French 
society. Beginning with the works of Rousseau and Thomas Jefferson, and continuing into the Barbizon school, the shift of focus to the countryside functioned as a safety valve for the pressure generated by the contradictions and rapid changes involved in the capitalist way of life. The primitive bond between the peasant and the soil was a guarantee of stability, a romantic link with a world which seemed to be disappearing rapidly. ${ }^{18}$

But the rural themes and scenes of peasant labour also had their place in the Russian realist tradition of the nineteenth-century and the 'Itinerants' school, led by llya Repin and Vasily Surikov. The community of artists founded in Abramtsevo in the 1870s brought to the forefront subjects from the daily life of ordinary country people, consciously seeking to promote the social mission of art, and paved the way for modernism through its 'discovery' of the national cultural heritage.

However, the internationalising character of the October Revolution ensconced the image of the worker in a new - purely class-based - context. Scenes of labour dominated the decorations of squares, streets and public buildings on the great holidays of May Day and the anniversary of the October Revolution. There were various iconographic traditions on which the artists could draw for their models: in the decorative panels designed by Boris Kustodiev to decorate Ruzheinaya Square in Petrograd in 1918, the figures of the carpenter, the woman reaping, the tailor, cobbler and baker appear against white, circular backgrounds, decorated with the tools of their trade or the products of their labour. The vivid, cheerful colours and the keen taste for the decorative attest to the survival of elements from popular crafts. The specific figures are not realistic depictions of real people, but archetypal models of their social status (Figure 8).

The monumental figure of the Master of the Earth, Sergei Gerasimov's inspired decoration for the Duma building in Moscow in the same year (Figure 9), uses a clear-cut, linear design to create an imposing, emblematic, almost biblical figure. We have the same sense when we look at the drawings for decorative panels made by an unknown artist to decorate the streets of Petrograd for the first anniversary of the revolution. The depictions are overwhelmingly realistic and descriptive, with references to romantic genre paintings, with some leanings towards symbolism or geometric tendencies.

The cubist forms used by Nathan Altman to surround the votive column of Alexander in Petrograd were among the most advanced solutions for their

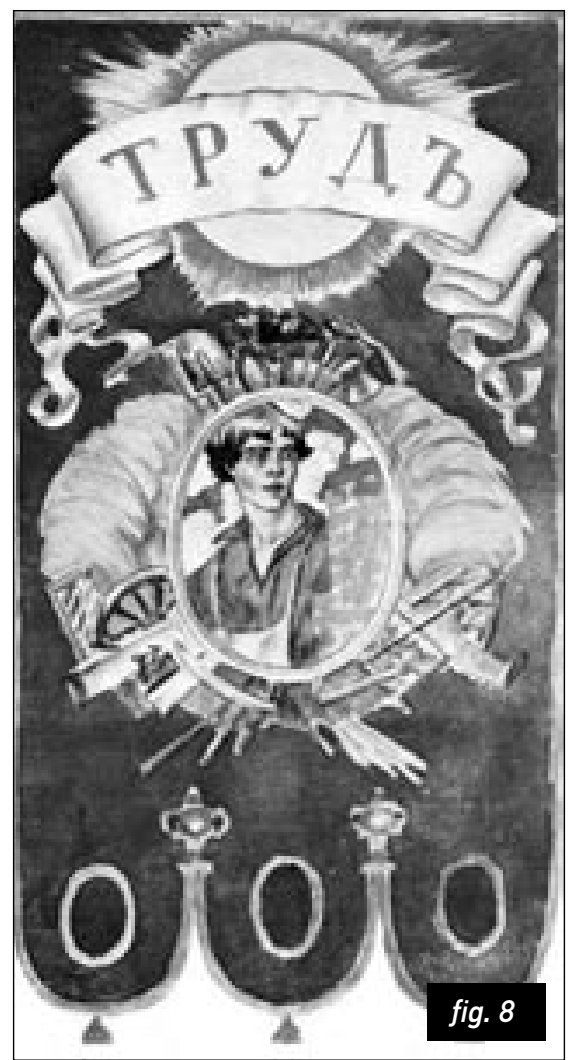




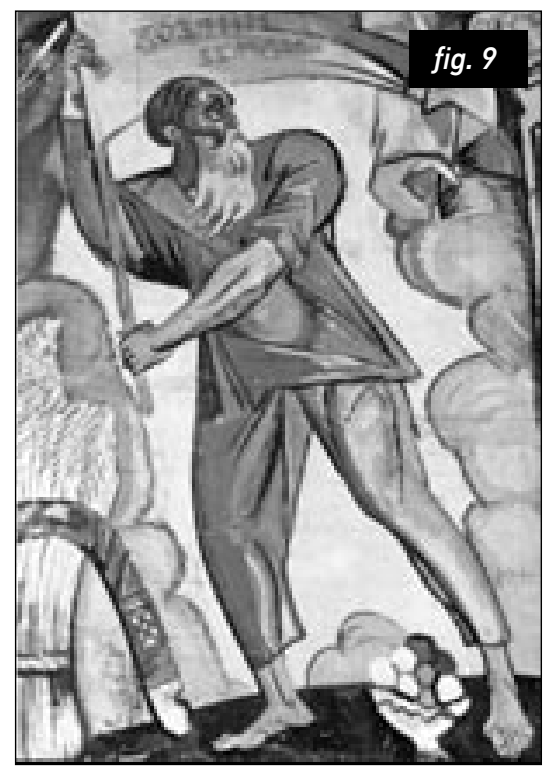

time. The flaming red, orange and yellow geometrical surfaces spinning around the column managed to expunge the absolutist past of the square with a "futurist parody" which has been judged as "a mixture of the moderate and the radical". 19

The process of constructing a new, complete model of the Soviet citizen was achieved in a characteristic manner in the poster designed by Adolf Strakhov in 1920 for the anniversary of women's emancipation, on 8 March (Figure 10). The striking female figure holding the red banner seems to have come from a late suprematist studio, although it retains marked elements of realism. Her hard, masculine traits are portrayed through the mingling and contrast of dark and light surfaces, graduated from white to dark grey, while the white lights endow the intensely sculptural form with a metallic, almost mechanical, brilliance.

The socialist version of femininity was replacing the bourgeois aesthetic with a new perception: woman now embodied the characteristics of her social class to the extent that she enlisted voluntarily in the cause, common to both sexes, of social reform. The dominant element in the process of constructing socialist female identity was not gender, but class. The new Soviet woman had to dedicate herself with all her strength to the cause of the international victory of the working class.

In the Strakhov poster the contrast of reality and utopia has been entirely effaced and the final transcendence has been achieved. The model is constructed. Art - with its prophetic force - has completed the genesis of the new woman. All that remains is for real individuals to be transformed in accordance with their visual archetypes.

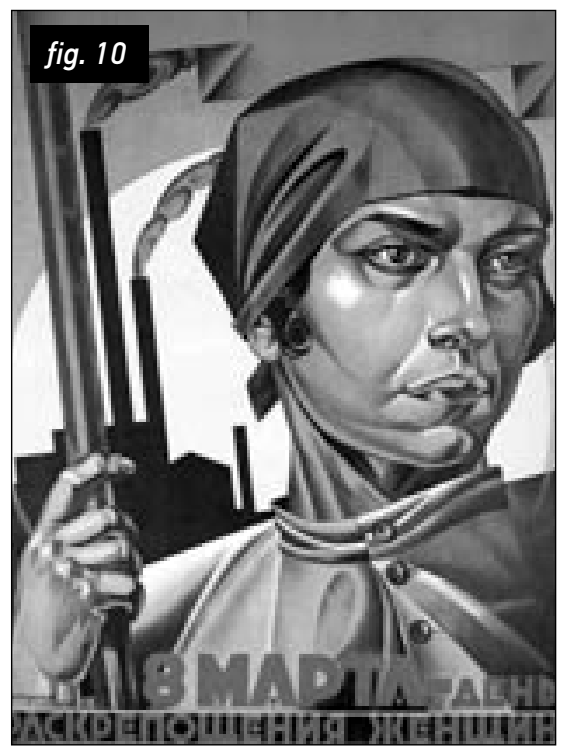

Propaganda posters, the massive decorative panels that covered the facades of buildings, and all other kinds of artistic intervention in public spaces - these were the basic arenas where cities were transformed for public holidays. The decoration of public spaces on holidays and anniversaries has its roots in Tommaso Campanella's utopian vision of the ideal city, as described in 
Civitas Solis, a city whose walls would be adorned with paintings, offering young people a visual education in natural science and history, thereby enhancing their pride in their city. The work of the Renaissance utopian socialist was a source of inspiration for Lenin, impelling him to design and put into practice immediately his own Programme of Monumental Propaganda.

"It seems to me", Lenin is said to have declared, explaining his idea to his associate Lunacharsky, "that this is far from naïve, and with certain changes, we could take his idea on board and put it into practice now. I would call what I have in mind 'monumental propaganda'." The basic principles of his idea consisted in placing "short but expressive inscriptions in various significant places, on suitable walls or on special constructions. These inscriptions should contain the most basic Marxist principles and slogans as well as, perhaps, tightly worked out formulations evaluating on or another great historical event ... Even more important than these slogans are in my opinion statues - be they busts or bas-reliefs of figures and groups." They would not be "of marble, granite and gold incised lettering, but modest, and let everything be temporary". ${ }^{20}$

The Programme of Monumental Propaganda did succeed in mobilising many artists in the cause of the representation and dramatisation of the shattering events which radically changed the form of Russian society. Since the memory of these events was so fresh, the character of the popular celebrations seemed spontaneous and improvised, as if they were just a natural sequel to the popular festivals, the religious celebrations of the countryside, carnivals, and participation in the theatrical performances organised by troupes in the Russian provinces. In fact there had been a well-established tradition of celebrating important events, like the signing of a treaty or the coronation of the Czar, with street processions and popular revelry. ${ }^{21}$ It seems that Lenin did a very good job inventing a new tradition by introducing the celebration of communist anniversaries. Using a folk tradition already in existence, he asked for the change of the sets and costumes and inserted into the calendar new ceremonies to mark the passage from the imperial past to the communist present and future.

Artist involvement in the creation of the sets for these socialist festivals was organised and systematic. Since there was little time for preparation, and resources and materials were limited, working groups of artists were assembled, and - with the assistance of numerous amateurs - managed to have the work done in time. In the early years the regime made no distinction in matters of style. All artists were welcome: academics and symbolists, and even the new 'futurists', as they were described somewhat disparagingly in the press. These first festivals - according to their reception in the press - were something like a battlefield between the avant-garde and more traditional artists, who remained faithful to realistic forms of representation. It is also a fact that the 'futurist innovations' of the 'leftist artists' often earned a lukewarm, sometimes even hostile, reception, since they employed a language barely intelligible to the masses. ${ }^{22}$ 
just twice: first in Petrograd, and then three years later in Moscow (Figure11). It was a political satire, a parody of the revolution, veiled in religion and didacticism. The plot was based on the conflict between the seven 'Clean' couples, symbolising the bourgeoisie, and the seven 'Unclean' couples, the proletariat. They had all gathered in a contemporary Noah's Ark, trying to survive the deluge of the Civil War. The bourgeoisie sought to restore the ancien régime, subjecting the 'Unclean' to forced labour and strict oppression. But the 'Unclean', after the deus ex machina intervention of the Ordinary Man, a role played by the author himself, rebelled. The Ordinary Man assumes the reins of the revolution and leads the 'Unclean' from hell to paradise, and finally to the Promised Land. In Act II Scene 16 he calls on them to follow him, making the following promise:

Not of Christ's heaven to ye I yell Where fasters lap sugarless tea. Of real earthly paradise I shall tell Unto ye!

Consider, what worth are Christ's blissful vales Or Evangelists' heavens full of hunger and gloom. In my heaven furniture fills sumptuous halls, Electricity serves you in stylish rooms. ${ }^{23}$

For the second production, the author was assisted with the sets by the sculptor Anton Lavinsky and the painter Vladimir Khrakovsky. ${ }^{24}$ They introduced a number of innovations in the arrangement of the sets and in the essential abolition of the distinction between the stage and auditorium. The stage was cov-

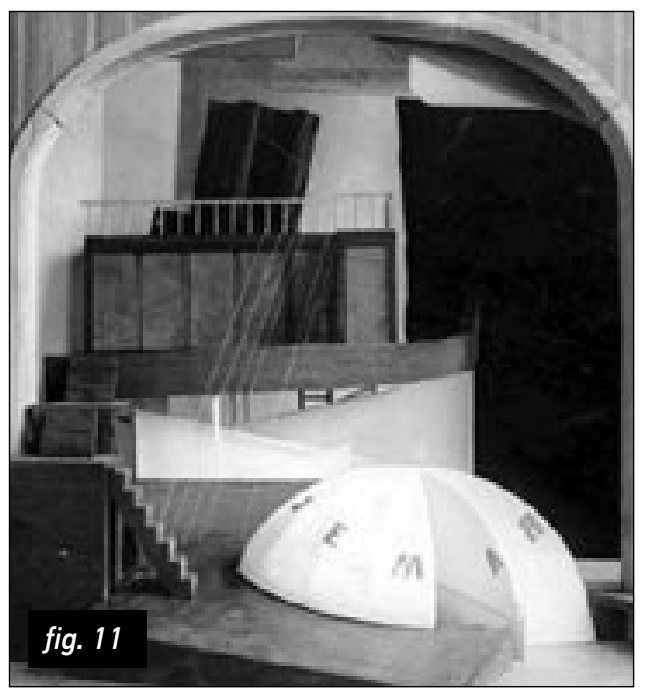
ered with platforms set at different levels and interconnected with ladders. A huge ramp ran down from the proscenium to the front row of the stalls, bearing a hemisphere representing, on one side, the Earth which, when the plot required it, revolved to present Hell. Heaven was placed to the rear, below the ceiling. Angels, devils, acrobats, heaven and hell - all paraded past in a utopian construction which abolished the familiar conventions of space and time.

The work was first staged by Mayakovsky - poet, painter, dramatist and ardent Communist - to celebrate the first anniversary of the October Revolution in 1918. The second - revised - production in 1921 was to mark the May Day workers' holiday. It opened on 1 May and played to highly appreciative audiences until 7 July at the Theatre No. 1 of the Russian Soviet Federated Socialist Republic, in Moscow ${ }^{25}$. Mayakovsky is quoted as saying: "The mystery is all that is great in revolution and the bouffe is its comic aspect. The verse of Mystery-Bouffe consists of the slogans of mass meetings, shouts from the streets and the language of newspapers. The action in Mystery-Bouffe is the movement of crowds, the conflict between classes and the struggle of ideas - it is a microcosm of the world within the walls of a circus." ${ }^{26}$

Addressing a semiliterate audience, Mayakovsky deliberately adopted a simplified, precise and pungent language, easily intelligible symbolism and familiar characters. Through the process 
of revolution, a new theatrical public was taking shape. The desired audience was no longer the upper or even petit bourgeois classes of pre-revolutionary Russia, but factory workers, soldiers who had left their villages behind, and women who supported the revolution. The theatre was transformed into an instrument of popular education, a medium for the cultivation of new political awareness.

Mystery-Bouffe was deemed, by the ideological pillar of the regime, Anatoli Lunacharsky, to be the most appropriate work with which to celebrate the anniversary of the revolution because it succeeded in conveying the bold and provocative spirit of that great event. The commissar did express reservations about the sets, doubting whether the ingenious innovations of the futurists would be understood by the public at large. He did, however, have faith in the direct language used by Mayakovsky, which

goes straight to the heart of the worker, the Red soldier, the typical impoverished peasant. It speaks for itself. It tells of the happy symbolic voyage of the working class, gradually freeing itself from its parasites after the revolutionary flood, and travelling via hell and paradise to the promised land which turns out to be our own sinful world, only cleansed by the flood of revolution. ${ }^{27}$

In its structure the play follows the logic of the Manichaean contrast of two worlds, locked in strife until one can prevail. To supply the iconography of the two worlds and the twists and turns of their conflict, religious imagery offered an inexhaustible store of topoi, easily identified in the imagination of the public. Heaven and hell - albeit transcendental realities - are still vivid enough as realities with which to embark on the journey towards Utopia.

Yet revolutionary praxis succeeded in transcending the distinction between utopia and reality, because the Promised Land, which is revealed in the third and final act of the drama, is not to be found in the world of imagination: it is a new reality already beginning to take shape in the GOERLO plan. The acronym stood for the State Commission for the Electrification of Russia, founded - by decision of Lenin - in February 1920 by some two hundred technicians, whose ambition was to build thirty high-tension generating stations with an output four times greater than that of pre-revolutionary Russia. ${ }^{28}$ Bringing electricity to all corners of Russia was for Lenin the yardstick with which to measure the successful implementation of revolutionary proclamations which had promised a dramatic improvement in the quality of life. Electrification was the necessary condition for economic recovery and mass industrialisation, for introducing the wonders of modern technology to Russia, providing heat and light for the people, and powering the cinemas which Lenin envisioned as the new popular form of leisure and education.

And this is why the sun, which features in the scenery designed by Mayakovsky for the final act, is an electric sun (Figure 12), dominating the whole stage and radiating light in all directions. It is the light of the new logos, the light of the triumphant revolution. Around it, airplanes revolve, factory chimneys emit smoke, trains run around on rails, pyramidal humanoid constructions carry the raw materials and tools of production, while the heroes of everyday life, the protagonists of the new era, bow down before its splendour, singing its praises: 
Above us, around us sunbeams shine.

Rejoice, all you who are strong.

Guild of world-builders, workers.

Life makes us more drunk than wine.

Warm us, burn bright and gay.

O sun, our sun!

Enough through the wide world we've tramped! Joined loving hands, take the place of chains! Join in a ring, play, play new games - games with the sun - play, sing $?^{29}$

The final supremacy of electric light is a modern metaphor for the new communist world that secularises every religious connotation connected traditionally with sunlight. The new classless society is not transcendental, wishful thinking, but a desirable reality under construction by means of technology and industrialisation. If utopia was traditionally thought as a different topos, clearly distinguished from reality, the theatre of the Revolution - and this is the case for many other artistic expressions from the same period - proves that utopia and reality, following Marxist ideology, not only co-exist but are also productively disintegrated into the process of designing the desired society of the future.

Soviet photomontage appeared in the midst of civil war, in 1920-21. Gustav Klucis based his first photomontage on his earlier painterly composition $D y$ namic City, one of the most experimental and influential constructivist works of art, part of the George Costakis Collection at the State Museum of Contemporary Art, Salonica (Figure 13). The experimental
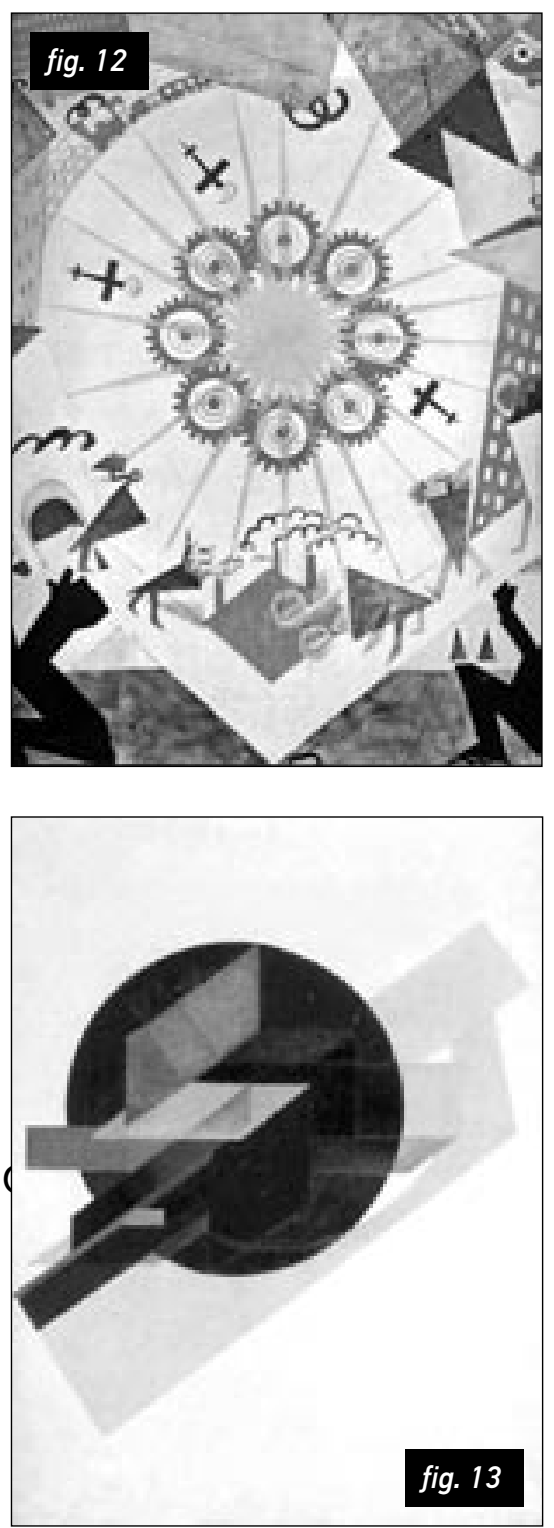
character of the work lies not only on the selection of the materials - a mix of sand and concrete - but mostly on the surpassing of the pure suprematist planar composition and the enforcement of the diagonal axis.

In the totally abstract image of the future city, Klucis introduced certain planes using photographic elements. A whole skyscraper, photographs of workers engaged in construction - all these elements suggest that the communist city is being built by the means of collective force (Figure 14). Using the method already known in the Dadaist circles of cutting and pasting photographic stills together with sheets of paper and aluminium foil on a painted surface, he then 
photographed his new composition, giving birth to a new, independent art form: the art of photomontage which coincided, not accidentally, with the overthrow of non-objectivity, the typical suprematist style. Klucis suggested that his photomontage could be looked from any way, thus overthrowing the singular point of view.
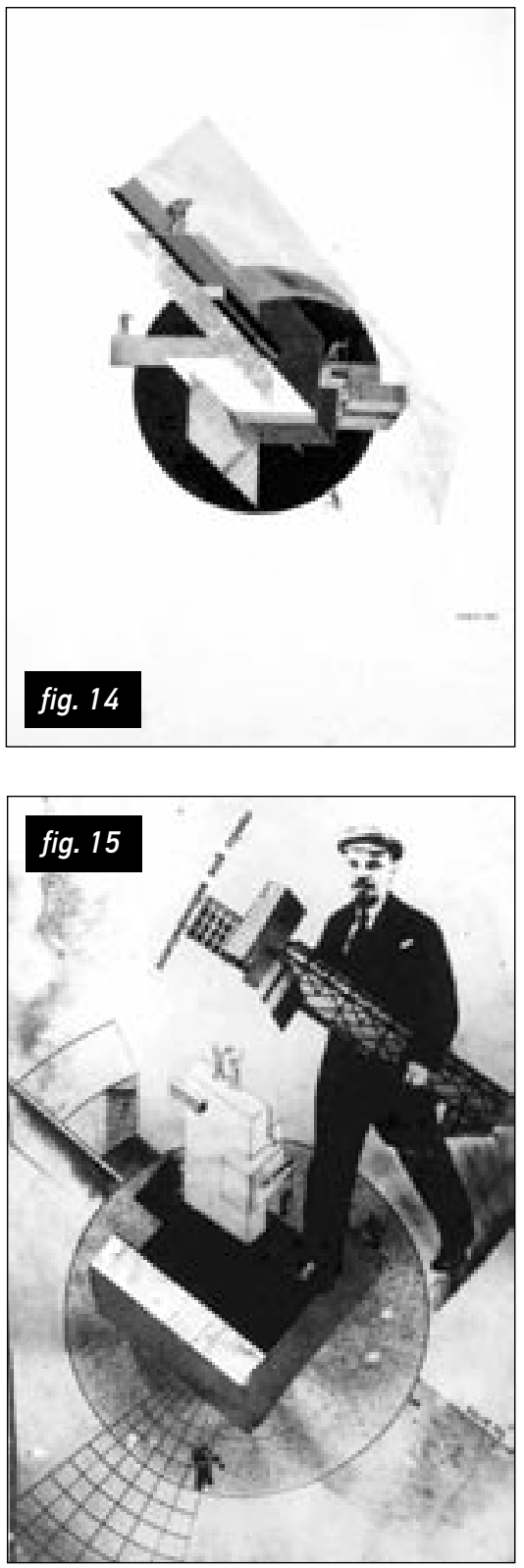

The next step was the political use of the photomontage: The poster (Figure 15) for the Eighth Congress of Soviets was designed by Klucis, based once again on the prototype of the Dynamic City where he introduced the image of the leader of the Revolution and he incorporated the communicational force of the political slogan. The poster was dedicated to the initiator of the Electrification Plan. The significance of this programme is very well known and formulated by Lenin himself thus: "Communism means Soviet rule + Electrification." The dynamism of the diagonal axis is still evident here, but social progress and industrialisation are clearly personified, since Lenin himself enters the circle triumphantly and makes a crucial step in the construction of new world carrying a pylon with fragments of skyscrapers.

It becomes clear that constructivism with all its propagandistic force in the context of revolutionary art, initiated a fresh ground for the exercise of visual communication and the formation of the experience of the city and public life. The intensification of social transformation with all its implications for everyday urban life gave birth to a new model for the understanding and representation of the relation between the leader and the social forces on which he relied. The need for new representational forms became evident in the wide application of photomontage, which later became the main aesthetic tool of Stalinist propaganda.

Photomontage is essentially undisputed proof of the capacity of art to "break down the limits between historical time, memory time and event time" ${ }^{\prime 30}$ and create a new, synthetic experience of city life. Klucis's first photomontages enabled the representation of a political perception of reality, where the vision of the electrified communist city of the future was not a utopian dream but a visible process already under construction. Even if this city is not yet ready, the artist can conceive and foretell it. The energetic presence of the worker-constructors assures the 
realisation of the leader's vision. These first photomontages can be seen as the visual counterpart of the dialectical conception of reality, first conceived by Marx in his Theses on Feuerbach and The German Ideology.

Even in 1926, the USSR remained a primarily rural country, with eighty-two per cent of the population employed in agriculture. Data from 1917 is not available, but twenty years earlier a national census disclosed that about eighty-three per cent of the rural population and about fifty-five per cent of the urban population was illiterate. From Victoria E. Bonnell, Iconography of Power. Soviet Political Posters under Lenin and Stalin, Berkeley: University of California Press, 1997, p. 4.

The revolutionary slogans written on the porcelains were obtained from texts by Marx, Bakunin, Danton, Lassalle, Ovid, Cicero, Thomas More, John Ruskin, Dostoyevsky, Tolstoy, Chernyshevsky, and Pisarev, and from excerpts from the Gospels and Confucius. Lydia Andreeva, "Soviet Ceramics 1917 -1935", Art into Production. Soviet Textiles, Fashion and Ceramics 1917-1935 (exhibition catalogue), London: Museum of Modern Art, 1984, p. 10.

Karl Marx, Selected Writings in Sociology and Social Philosophy, eds T. B. Bottomore and M. Rubel , London: Penguin Books, 1988, p. 82.

Marx, Selected Writings, p. 82.

"From the outset, 'spirit' is cursed with the 'burden' of matter, which appears in this case in the form of agitated layers of air, sounds, in short, of language. Language is as old as consciousness, language is practical consciousness, as it exists for other men, and thus as it first really exists for myself as well. Language, like consciousness, only arises from the need, the necessity of intercourse with other men. Consciousness is therefore from the very beginning a social product." From The German Ideology (1845-6), in Marx, Selected Writings, p. 85.

Andrei Zhdanov (1896-1948), "Speech to the Congress of Soviet Writers", in Charles Harrison and Paul Wood (eds), Art in Theory 1900-2000. An Anthology of Changing Ideas, Malden, Mass.: Blackwell, 2003, p. 426.

Zhdanov, "Speech to the Congress of Soviet Writers", p. 428.

The poster belongs to the Merrill C. Berman Collection and has been published in Leah Dickerman (ed.), Building the Collective. Soviet Graphic Design 1917 -1937. Selections from the Merrill C. Berman Collection, New York: Princeton Architectural Press, 1996, pp. 58-9.

"Unlike the pyramid, the star", according to Richard Stites, "has no prehistory in the Russian radical tradition." Cited in Dickerman, Building the Collective, p. 40.

Jean-Claude Marcadé, "Of Light", in Miltiades Papanikolaou (ed.), Light and Colour in the Russian AvantGarde. The Costakis Collection (exhibition catalogue), Cologne: Dumont, 2004, p. 435. 
David Davidovich Burliuk (1882-1967), Portrait of the Futurist Poet Vasily Kamensky, 1917, oil on canvas, 104 x 104 cm, in Vladimir Leniashin (ed.), Soviet Art 1920s-1930s, Moscow: Sovietsky Khudozhnik, 1988, pp. 37, 244.

George L. Mosse, The Image of Man. The Creation of Modern Masculinity, Oxford: Oxford UP, 1996, p. 123.

See Snejanka Dobrianowa-Bauer, "Looking Back for a New Vision. The influence of Russian icons and lubki on Russian modernism", in: Snejanka Dobrianowa-Bauer (ed.), When Chagall learnt to Fly. From the Icon to the Avant-Garde (exhibition catalogue), Tübingen: Legat 2004, pp. 238-9, 16-19.

"David Burlyuk, one of the protagonists of Cubo-Futurism, was another well-known collector of icons and traditional craft." See Verena Krieger, "The interest of the Avant-Garde in the pictorial concept of the Icon”, in Dobrianowa-Bauer (ed.), When Chagall learnt to Fly, pp. 21-23, 240.

Also called Workers' Triumph. From the book Russian Placards 1917-22, Petrograd: ROSTA, 1923 (State Museum of Contemporary Art archive).

Cited in Elena Barkhatova., "Modern icon, or toll for mass propaganda? Russian debate on the poster", in Alla Rosenfeld (ed.), Defining Russian Graphic Arts 1898-1934. From Diaghilev to Stalin (exhibition catalogue), New Brunswick, NJ: Rutgers UP, 1999, p. 136.

Some of the posters bear the instruction: "Print 2,000 copies", or "Print as many as you can (fifteen hundred or two thousand)". See Yevgeny Kovtun, Avant-Garde in Russia 1920-1930, Bournemouth: Parkstone. 1996, p. 33.

As Michelet pointed out in Le Peuple in 1846: "The peasant is not only the most numerous part of the nation, he is the strongest, the healthiest, and, carefully weighing both the physical and the moral factors, the best as a totality." Cited in Linda Nochlin, Realism, London: Penguin, 1990, p. 115.

James von Geldern, Bolshevik Festivals 1917-1920, London: University of California Press, 1993, p. 96.

From a text by A. V. Lunacharsky, "Lenin o monumentalnoi propagande", in Lenin I izobrazitelnoe iskusstvo, Moscow, 1933, pp. 139-40, cited in Vladimir Tolstoy, "Art born of the October revolution", in Vladimir Tolstoy, Irina Bibikova, Catherine Cooke (eds), Street Art of the Revolution. Festivals and Celebrations in Russia 1918-33, London: Thames and Hudson, 1990, p. 12.

Catherine Cooke, "The Artists are mobilized", in Tolstoy et al., Street Art of the Revolution, p. 35.

See the newspaper articles by A. A. Sidorov, "Two years of Russian art and artistic activity" and M. V. Dobuzhinsky, "A bomb or a firecracker: a conversation between two artists", reprinted in English translation in Tolstoy et al., Street Art of the Revolution, pp. 68 and 51-52.

"Mystery-Bouffe. An heroic, epic and satiric portrayal of our epoch", in Alexander Ushakov (ed.), Vladimir Mayakovsky. 3 Plays/Articles/ Essays, Moscow: Raduga, 1987, p. 47.

For the scenic innovations of Mystery-Bouffe, see Edward Braun, "Constructivism in the Theatre", in Hayward Gallery (ed.), Art in Revolution. Soviet Art and Design since 1917 (exhibition catalogue), London: Arts Council of Great Britain, 1971, pp. 60-63.

Kostantin Rudnitsky, Russian and Soviet Theater 1905-1932, London: Thames and Hudson, 1988, p. 62.

V. V Mayakovsky., Teatr I kino, vol. 1, Moscow 1954, p. 322. Cited in Rudnitsky, Russian and Soviet Theater, p. 42. 
Lunacharsky's praise of Mystery-Bouffe was published in the Petrogradskaya Pravda in November 1918. The extract is taken from the English translation in Edward Braun, "Constructivism in the Theatre", in Hayward Gallery (ed.), Art in Revolution, p. 78.

Nicoletta Misler, "Kliment Redko and the electric avant-garde", in Miltiades Papanikolaou (ed.), AvantGarde. Masterpieces of the Costakis Collection (exhibition catalogue), Thessaloniki: State Museum of Contemporary Art, 2000, p. 76.

From the "Hymn to the Sun" in Mystery-Bouffe, p. 73

Lutz Becker, “Dynamic City. Design and Montage”, in: Lutz Becker, Richard Hollis (eds), Avant-Garde Graphics 1918-1934. From the Merrill C. Berman Collection (exhibition catalogue), London: Hayward Gallery, 2004, p. 11.

1 Stamp of the RSFSR, "The Liberated Proletarian", 1921

2 Mikhail Adamovich, Plate, 1921, painted porcelain, D. $24.4 \mathrm{~cm}$., State Museum of Contemporary Art - Costakis Collection, Thessaloniki.

3 Car of the agit-prop train “The October Revolution”, 1919, photograph.

4 Mikhail Cheremnykh and Vladimir Mayakovsky, ROSTA window, No 744, 1920. Text: We've taught a number of mighty powers not to make war on us, but we've still got to be prepared. 1. We succeeded in teaching a lot of them. 2. But there are still a lot sharpening their knives. 3. While entering upon years of work. 4. Be ready for this too, comrade!

5 Dmitry Moor, Poster "Soviet Russia is a camp under siege. Defend it!", 1919, Revvoensovet [Revolutionary-Miltiary Council of the Republic], n. $29,90.5 \times 67.6 \mathrm{~cm}$.

6 David Burliuk, "Portait of the Futurist Poet Vasily Kamensky", 1917, oil on canvas, $104 \times 104 \mathrm{~cm}$.

7 Vladimir Lebedev, “Worker's Triumph”, from the book Russian Placards 1917-1922, ed. ROSTA, Petrograd 1923, State Museum of Contemporary Art - Costakis Collection, Thessaloniki.

8 Boris Kustodiev, Panel design for the festive decoration of Ruzheinaya Square, Labor, Petrograd, 1918.

9 Sergei Gerasimov, Design for the festive decoration of the former Duma Building, Master of the Land, Moscow, 1918.

10 Adolf Strakhov, Poster “8 March - Day of Women's Emancipation”, 1920.

11 Set Design for the Mystery-Bouffe, photograph.

12 Vladimir Mayakovsky, Setting for Mystery-Bouffe, 1919, Mayakovsky Memorial Museum, Moscow.

13 Gustav Klucis, "Dynamic City”, 1919, oil with sand and concrete on wood, 87 x $64.5 \mathrm{~cm}$., State Museum of Contemporary Art - Costakis Collection, Thessaloniki.

14 Gustav Klucis, "Dynamic City”, photomontage, 1919, photograph, State Museum of Contemporary Art - Costakis Collection, Thessaloniki.

15 Gustav Klucis, poster "The Electrification of the Entire Country", photomontage, 1920, photograph, State Museum of Contemporary Art - Costakis Collection, Thessaloniki. 